\title{
Spawning Economic Development through Enforcement of Justiciable Human Right to Water in South Africa
}

\author{
Devi Datt Tewari \\ School of Economics and Finance, \\ Faculty of Management Studies, \\ University of Kwazulu-Natal \\ Durban, South Africa \\ Emailtewari@ukzn.ac.zaordevitewari@yahoo.com \\ doi:10.4314/gjds.v8i1.6
}

\begin{abstract}
In recent years, the human rights based approach to development has become a global phenomenon after the World Summit of 2005 when the members of United Nations resolved to integrate the promotion and protection of human rights into national polices. South Africa as a signatory to the above adopted this approach. The rights approach has been used in the water sector among others. In that sector, the main policy instrument of action and used by the state is to develop the underdeveloped water sector of the economy. South Africa has adopted a two sector price policy toward water - a zero price or free basic water delivered to indigent citizens and the other market-based price to citizens endowed with purchasing power. The human rightsbased approach to economic development is purveyed through constitutional provisioning of human rights to water for the economically poor citizens of the country; as a result, the human right to water has become a justiciable activity in the country. The achievements of South Africa in this respect are laudable, for more than 85 per cent population is receiving the free basic water.
\end{abstract}

Key Words: Human Rights, Property Rights, Contractual Rights, Justiciable, South Africa, Free Basic Water 


\section{Introduction}

The human rights-based approach (HRBA) to development recognizes the role of conscious planning to eradicate or lessen poverty by ensuring that minimum living standards of the people are provided by the state. This entails that constitutions of countries recognize the role of human rights and make them a part and parcel of the judiciary so that human rights are enforceable by the courts of the country (UNFPA/ Harvard School of Public Health, 2010). This entrusts the governments with responsibility of developing adequate laws, policies, institutions, administrative procedures and practices, and mechanisms of redress. The human rights based approach is deemed superior as decisions are made directly by local communities, rather than what external agencies consider appropriate for them; and, it also builds upon "elements of traditional good programming practice such as extending and deepening participation; ensuring local ownership of development processes; strengthening the accountability of all actors in the process" (UNDP, 2006: 5).

In the World Summit Outcome Document of 2005, the "member states of United Nations unequivocally and unanimously agreed to support the further mainstreaming of human rights throughout the United Nations System" (UNDP, 2006). Some seven human rights treaties have been signed so far: the Covenant on Economic, Social and Cultural Rights (ICESCR); the Covenant on Civil and Political Rights (ICCPR); the Convention of Elimination of Racial Discrimination (CERD); the Convention on Elimination of All Forms of Discrimination Against Women (CEDAW); the Convention on the Rights of the Child (CRC); the Convention Against Torture; the Convention on Migrant Workers and Their Families (MWC) (http://www.ohchr.org/english/bodies/index.htm) (UNDP, 2006). South Africa being a signatory to many of these has adopted the human rights-based approach (HRBA) to development through constitutional provisioning of resources including water for the indigent citizens of the country. The water right legislation is a main policy instrument of this approach in the country. The acknowledgement and assurance of human right to water to people brings various economic advantages (Gleick, 1999).

The water legislation after the democratic transition in South Africa made a marked shift from previously existing laws on water in the country (Tewari, 2009a: 693). The Constitution of South Africa, which was adopted in 1996, contains a Bill of Rights (Chapter 2) which ensures the rights of individuals to environment and water. Under section 27 (1) of the Constitution, "everyone has the right to have access to: (a) healthcare services.... (b) sufficient food and water; (c) social security...; and (2) the state must take reasonable legislative and other measures, within its available resources, to achieve the progressive realization of each of these rights" (RSA 1996a: 11-13; Tewari, 2009a: 702). Poverty abounds in South Africa; about 35 per cent people live below the poverty line of US $\$ 2$ per day or R174 per month in 2005 prices (UNDP, 2005: 11). In 1997, about 12-14 million people were without access to safe water and about 20 million were without access to sanitation in South Africa (Department of Water Affairs and Forestry ( DWAF), 1997). Obviously the state has a big responsibility to shoulder to develop this sector of the economy. 
The major objective of this study is to discuss the ethical basis of human right to water in South African context with respect to the justiciability of human rights to water use and how this approach is being used for stimulating economic development, in particular with respect to Millennium Development Goals (MDGs). The more specific objectives of the study are to discuss the:

- ethical basis of the human right to water use vis a vis other water rights, such as contractual and property rights;

- historical events and policy legislations that led to human right to water use as an instrument of engendering economic development in South Africa; and

- impacts of human rights-based approach to development in ensuring free basic water to all indigent citizens of the country, especially with respect to achieving the MDGs.

The material of this study is organized under 5 sections. The ethical bases of the water rights, with special focus on human right to water, are explored in section 2 . The evolution of human rights-based approach to development with respect to human right to water use in South Africa is briefly discussed in section 3; this section dwells upon the issues related to the justiciability of human rights to water vis a vis the water privatization initiative in the country. The resulting developmental achievements in terms of delivery of free basic water and its associated costs and benefits are highlighted in section 4 . Conclusions and policy implications are discussed in the section 5 .

\section{Ethical Basis of the Human Right to Water (Hrw)}

"A right is a special advantage that someone gains because of his/her particular status; the special advantage may include gaining a liberty, a power, an entitlement or an immunity and the particular status may refer to one's position as human being, a woman, a minority, an animal, a child, or a citizen of a country" (Stephen F. Austin State University, No date, see for more details, http://www2.sfasu.edu/polisci/abel/ConstitutionalLawII/ RightsTheory.htm). The word "right" connotes a set of rules that grant freedom or any kind of benefits to individuals or a group of individuals that are granted by the society at large. The three basic ethical theories which provide different rationales for existence of rights in general or water rights in particular are: consequentialism, deontology, and contractraian ${ }^{37}$. Each of these is briefly discussed with respect to different types of water rights including human-rights to water. Three types of water rights are identified in the literature: property rights, contractual rights, and human rights. The property rights

37 The brief description on various theories is largely based on a peer reviewed resource from the Internet Encyclopedia of Philosophy. 
are associated with consequentialism, while contractual and human rights are based on contractarian and Kantian ethical theories, respectively.

Property right to water refers to the right to abstract water from a water resource granted by the state. In South African parlance, this is equivalent to authorization or permit of water use (Tewari, 2009a: 704). The property right is also legal claim to access to water. There is an institutional literature which concludes that formalization of property rights and assurance of it ensures the good economic incentive for progress (Durnev et al., 2009). Many countries such as such as Brazil, Mexico, Chile and South Africa have launched such a programme under the auspices of the World Bank to provide security and certainty of legal title to rights-holders so that they can be protected by the law if infringed upon by others (Tewari, 2009b).

Contractual right refers to the right of exchange of water between buyers and sellers. This happens due to scarce nature of water which leads to the formation of a market. The contract between the seller and buyer of water is a legal right. Here the use of water by the seller is in exchange of payment by the buyer. Such a payment is necessary in lieu of services so that water facilities can be funded. The World Panel on Financing Water Infrastructure report has sketched out the mechanisms of financing water infrastructures and the objective hence is to produce the enabling environment for making water affordable to all (Camdessus et al., 2003).

Finally, the state can legislate that some basic minimum water needs of the individual, such as drinking and sanitation, must be provisioned. By making provision for minimum water needs of individuals through constitutional laws, the human right to water becomes justiciable or in other words such a right can be enforced by the courts. However, a balance has to be sought among three types of water rights. A comparison of three forms of water rights, adapted from Overseas Development Institute (ODI) is provided in Table 1.

Table 1: A comparison of legal forms of the right to water

\begin{tabular}{|l|l|l|l|}
\hline Characteristics & $\begin{array}{l}\text { Human Right } \\
\text { as per General } \\
\text { Comment 15 }\end{array}$ & $\begin{array}{l}\text { Contractual Right } \\
\text { under contracts of water } \\
\text { services }\end{array}$ & $\begin{array}{l}\text { Property Right } \\
\text { as per typical } \\
\text { formalization scheme }\end{array}$ \\
\hline $\begin{array}{l}\text { Governing } \\
\text { Ethical model }\end{array}$ & Kantianism & Contractarian & Utilitarian \\
\hline Security & $\begin{array}{l}\text { Emphasis on security } \\
\text { of person (health and } \\
\text { nutrition). }\end{array}$ & $\begin{array}{l}\text { Emphasis on security } \\
\text { and continuity of } \\
\text { supply. }\end{array}$ & $\begin{array}{l}\text { Emphasis on security } \\
\text { and continuity to give } \\
\text { certainty of title. }\end{array}$ \\
\hline
\end{tabular}




\begin{tabular}{|c|c|c|c|}
\hline Water Use(s) & $\begin{array}{l}\text { Focus on personal and } \\
\text { domestic uses of each } \\
\text { individual user. }\end{array}$ & $\begin{array}{l}\text { Focus on urban use } \\
\text { (including personal and } \\
\text { domestic uses) under } \\
\text { individual contracts for } \\
\text { supply to premises. }\end{array}$ & $\begin{array}{l}\text { Can relate to water } \\
\text { use to municipality, } \\
\text { irrigation district, } \\
\text { community group etc. }\end{array}$ \\
\hline $\begin{array}{l}\text { Economic or } \\
\text { social good }\end{array}$ & $\begin{array}{l}\text { Water is treated } \\
\text { as a social and } \\
\text { cultural good, and } \\
\text { not primarily as an } \\
\text { economic good. }\end{array}$ & $\begin{array}{l}\text { Focus on commercial } \\
\text { and financial aspect but } \\
\text { contract may also reflect } \\
\text { social concerns such as } \\
\text { through tariffs. }\end{array}$ & $\begin{array}{l}\text { Focus on economic } \\
\text { and financial aspects } \\
\text { such as tradability and } \\
\text { bankability. }\end{array}$ \\
\hline Payment & $\begin{array}{l}\text { No free water } \\
\text { but affordable } \\
\text { with freedom } \\
\text { from arbitrary } \\
\text { disconnection. }\end{array}$ & Water is a paid good. & $\begin{array}{l}\text { Fees for registration } \\
\text { of rights and regular } \\
\text { charges during permit } \\
\text { term. }\end{array}$ \\
\hline Universality & $\begin{array}{l}\text { Water to become } \\
\text { available to all } \\
\text { citizens. }\end{array}$ & $\begin{array}{l}\text { Not universalized but } \\
\text { tariffs may be designed } \\
\text { to provide subsidies for } \\
\text { poor. }\end{array}$ & $\begin{array}{l}\text { Water users have to } \\
\text { obtain permits from the } \\
\text { government. }\end{array}$ \\
\hline
\end{tabular}

Source: Adapted from ODI (2004) and ethical literature reviewed by the author.

Property rights are associated with consequentialism doctrine. This doctrine suggests that an action is right if it promotes the best consequences which maximize happiness. Utilitarianism is an influential consequentialist theory developed by Jeremy Bentham and John Stuart Mills. In his book "The Principles of Morals and Legislation", Bentham (1781, Chapter 1) says that "Nature has placed mankind under the governance of two sovereign masters, pain and pleasure". John Stuart Mill (1861) modified Bentham's version of utilitarianism by adding lower and higher types of happiness. In other words, higher pleasures give a greater degree of utility than lower pleasures, as someone who experienced both will forfeit the lower for higher. Morality is not a ground for Bentham's concept of right, rather it is the calculus of pain and pleasure which drives the individual or society to decide what is wrong and right. The property rights of water directly emanate from this theory and assert that an individual owns the water use for ever unless these rights are sold or bought to other parties.

The human right to water use is associated with the second deontological stream of ethical thought referred as Kantianism. Kantianism, unlike utilitarianism which focuses on pleasure-seeking and pain-avoiding human nature, is grounded in the belief that human beings are capable of making moral choices freely and rightness of an action is therefore not dependent upon the utility. Kant presumes that human beings are rational in that they can make moral choices and enjoy autonomy or freedom. Therefore, we cannot treat human beings as material objects. Rights therefore emanate from a moral basis of society. 
The contractual water right is linked to the third contractarian theory which has multiple versions. The four major architects of this doctrine are Thomas Hobbes, Jean Jacques Rousseau, John Rawls and, Robert Nozick. Both Hobbes and Rousseau developed the theory of social contract but with different assumptions. Hobbes believed that human beings are by nature competitive and acquisitive and they came together to contract with another for mutual protection (Hobbes, 1651). This is said to be moral contract in the sense that contract protects the group and their property from all enemies. Hence, the individuals have no right to complain about the provisions made by the state or government. However, Rousseau presumed that human beings are peaceful and solitary, not competitive or acquisitive. When people live in nature, there is no bonding between them, but when they live in community, they engender change in the human nature and behaviour and this finally leads to a social contract. Thus, in the world of Hobbes and Rousseau, rights are not absolute but constrained by the rules of the state which are made to serve the people who banded together into a social contract. Locke's concept of right is different from the authoritarian view of social contract by Hobbes and Rousseau; Locke's view implies that governments cannot mandate anything without the popular consent of the people and that people have some natural rights irrespective of the type of governments, religion, and society. Locke was thus referring to what, I suggest, we now term "human rights" under the United Nations (UN).

Unlike Hobbes and Rousseau, Rawls and Robert Nozick are the two contractarians who have supported the human right aspects very strongly. For example, Rawls concept of right is related to the greatest good of the least advantaged section of the society. Rawl's social contract theory is therefore explicitly Kantian as it is intuitive. Similarly Robert Nozick, a contractarian of modern time, assumed that people have natural or moral rights which are different from legal rights. Hart (1955, 1973, 1979, 1994) also recognized the existence of both legal and moral rights. Although Bentham (1782) emphasized the legal rights only, Mill (1861) recognized both moral and legal rights and the divergence between the two in societies. This confirms the support for human rights or moral rights long back in the history.

In recent years, human rights have become the new instrument to bring developmental changes in the world (Cornwall and Nyamu-Musembi, 2004). Many world bodies including the United Nations and country governments have proclaimed the rights of individuals to ensure the ethical standards. Although the International Bill of Human Rights does not specifically mention the human right to water, it entails access to water as a right to life, liberty, security of person (see United Nations (1948), Article 3 of the Universal Declaration of Human Rights, 1948, see http://www.un.org/en/documents/udhr/). The International Covenant on Economic, Social, and Cultural Rights (ICESCR) adopted by the United Nations in 1966 and later enforced since 1976 did recognize the human right to water indirectly under article 11 (right to adequate food) and article 12 (right to adequate living standard including adequate food, adequate clothing and adequate housing) (United Nations, 1966). 
However, the United Nations Committee on Economic, Social and Cultural Rights (UNCESCR, 2002) affirmed in the General Comment No 15 of 2002 (GC-15) the right to access to supply of safe and adequate water clearly. The General Comment No. 15 (GC15) entitles "every human being to sufficient, safe, acceptable, physically accessible and affordable water for personal and domestic uses" (GC15, para 2). As per the UNCESCR, the accessibility of water refers that:

1. It must be physically accessible and be within safe physical reach of each household or institution;

2. Water must be economically accessible as well, i.e., it should be affordable;

3. The access should be provided on non-discriminatory basis;

4. Provision should be made for sharing of information about water issues

$$
\text { (GC15, para12). }
$$

The sufficiency of water requires that the quantity of water be adequate and safe (free from micro-organisms, chemical substances and radiological hazards) for personal (drinking, personal sanitation) and domestic (food preparation, household cleaning, etc.) uses (GC-15 para12). The sufficiency is to be determined by what is necessary "to prevent death from dehydration, reduce the risk of water related disease and provide for consumption, cooking, personal and domestic hygienic requirements" (GC15, para 2).

The ICESCR calls for a "progressive realization of human right to water in the world while acknowledging constraints on available resources" (ODI, 2004; UNCESCR, 2002). The General Comment-15 thus recognizes the right to water as independent human right (Bluemel, 2004). This has been interpreted as to mean a number of things in the literature:

1. The entitlement to fresh water is legal, not a charity driven water supply;

2. The basic and improved level of access to water is be given and accelerated;

3. Least served are better targeted in order to reduce inequalities.

4. Empowerment of communities and vulnerable groups to enable them to make decisions on water resources;

5. The human rights system developed by the United Nations would be used to monitor the progress of governments in realizing the right to water and to hold governments accountable (Blumel, 2004: 973-974).

Recent international human right treaties include more direct references to right to water. For example, Article 14(2h) of the Convention on the Elimination of All Forms of 
Discrimination Against Women (CEDAW) in 1979 specified that State Parties shall ensure the women the right to "Enjoy adequate living conditions, particularly in relations to water supply" (UN, 1979, see http://www.un.org/womenwatch/daw/cedaw/text/ econvention.htm; Dubreuil, 2006: 6). The African (Banjul) Charter on Human and People's Rights adopted in 1981 recognizes the satisfaction of basic human needs for water and food as right to development (OAU, 1981, see http://www1.umn.edu/humanrts/instree/ z1afchar.htm). The African Charter on the Rights and Welfare of Child adopted in 1990 under Article 14(1) ensures the provision of adequate nutrition and safe drinking water for every child (Dubreuil, 2006: 6). The Human Rights Council of Australia describes the right to development as inalienable human right (HRCA, 2001); thus water can be important part of this development strategy. Some 8 countries including South Africa have adopted the human right to water as a legal entitlement (Hale, 2007). The General Assembly of United Nations on 28 July, 2010 adopted the Resolution 64/292 the Human Right to water and Sanitation which recognizes "the right to safe and clean drinking water and sanitation as human right" (UN, 2010).

\section{Evolution of the Human Rights-Based Approach (HRBA) to Develoment in South Africa}

The new water demand management paradigm of 1990 called for the water management through efficient pricing (Gleick, 2000: 131). Since the efficient pricing can be done only through market-derived prices, the paradigm had promoted the privatization of water resources, especially in Africa by the World Bank (WB) and International Monetary Fund (IMF) - the two key financial organizations in the world. For example, some 12 countries in Africa in 2000 were given conditional loans by the WB and IMF subject to privatization of water utilities (Grusky, 2001: 4). Privatization of utilities entails charging the full cost of operating, maintaining, expanding, and a reasonable rate of return on capital. This finally brings profits to the businesses and at the same time miseries on poor populace in terms of water disconnections (Bayliss, 2001). Also, privatization spawns some irreversible damages as water has vital social, cultural, and ecological roles to play; the market alone cannot be right instruments to allocate water and attain efficiency (Gleick et al., 2002).

Historically speaking, privatization of water services was bolstered up in South Africa during 1996 when the African National Congress (ANC) produced the Growth, Employment and Redistribution (GEAR) policy document which focused on reducing deficit and attracting investment and reducing inflation and interest rate (RSA, 1996b). Privatization accentuated the "conflicts between the water uses due to human rights and other non-human rights (contractual and property rights) related aspects" (Tewari, 2009b). In South Africa, prepaid water meters were used as a tool to regulate the water supplies to people due to privatization drive; when the residents failed to pay, their water supplies were automatically shut-off. As a result, some residents had to resort to alternative sources of water which were not conducive to health. For example, some 259 people died of cholera and about 10000 people fell sick due to water borne diseases 
between August 2000 and February 2002 in South Africa (Thompson, 2003: 2). In 2001, about 10 million people were cut off from water and electricity and government charged 87 activists with malicious damage for protesting against shutoff (Thompson, 2003: 3). At the global level, about one billion people in the world are deprived of access to basic water supply (WHO, 2000). The government of South Africa thought of these grim realities and instituted a new approach to uplift her people.

In early 1990s, a programme of action was developed by the ANC, its allies, civic bodies and a range of experts; it was called the Reconstruction and Development Programme (RDP). The RDP recognized the "need for housing, supply of electricity, land reform, and a new system of social security and social welfare, supply of clean water, health care, job creation through public works, education and training" (ANC, 1994). It was posited that the minimum safe and clean water should be provided to all indigent citizens throughout the country; for this purpose, a supply of 20-30 litres per capita per day to all households in two years within a distance of 200 meters from the dwelling site was recommended; furthermore, within a period of 5 years, this amount was recommend to be increased to 50-6o litres per day (ANC, 1994: 30).

In 1994, a White Paper on Water Supply and Sanitation Policy was produced. This was revised in 1997 (Department of Water Affairs and Forestry (as it was known then), 1994, and 1997). In 1996, the "right to have access to sufficient water" was included in the new South African constitution (Section 27(1)). Problems of access to water for poorer sections of the society were realized and a policy was formulated that all South Africans should receive a basic water supply free of charge. This was seen in consonant with the declaration of Rio Earth Summit (UNCTAD, 1992) which defined water as social and economic good, not economic good alone as done under Dublin Principles (ICWE, 1992).

Some 10 million people out of 36 million were deprived of access to safe water in South Africa in 1994 (SCOWSAS, 1991). The programme of enhancing access was geared and the government adopted the model of decentralized water management, leaving this to be implemented by the municipalities at the field level and DWAF was tasked to fulfil the role of policymaker and framework provider (Muller, 1993; Asmal, 1996). A free basic water policy was warranted for various reasons in the country (Balfour et al., 2005: 5-7). Firstly, water is an essential commodity for life and rightfully required for life to continue. Secondly, access to water adds to improved public health which finally contributes to economic growth of the country. Thirdly, the municipalities can meet their constitutional prescribed development obligations. It was finally materialized into a legal requirement in terms of the Water Services Act (WSA), 1997.

The WSA, 1997 regulates the right of access to water and state's obligation and Section 3 provides that (RSA, 1997):

(1) Everyone has a right of access to basic water supply and basic sanitation. 
(2) Every water services institution must take reasonable measures to realize these rights.

(3) Every water services authority must, in its water services development plan, provide for measures to realize these rights.

(4) The rights mentioned in this section are subject to the limitations contained in this Act. Section 9 of the WSA Act provides that the Minister may from time to time prescribe "compulsory national standards" relating, amongst other, to the provision of water services and the "effective and sustainable use of water resources for water services".

These regulations relating to compulsory standards and measures were published in Government Gazette No. 22355, Notice R509 of 2001 (8 June, 2001). Under Regulation 3, as per WSA 1997, the prescribed "basic water supply" was set to 25 litres per person per day within 200 meters of household (Water Services Act, 1997, Section 9, Regulation 3(b); Constitutional Court of South Africa, 2009) $)^{38}$.

Durban Municipality was a pioneer institution in terms of adopting the free basic water concept and acted out it in 2000 (Brocklehurst, 2001). Of the 2.5 million people in Durban, about half a million were without household connections and used public standpipes and about 20 thousand households were illegally connected (Muller, 2008a: 73; Brocklehurst, 2001). The Ethekwini Municipality decided not to enforce payment after weighing the costs and benefits and decided to provide some free water to all users of the restricted access system; it was funded by cross-subsidies from higher-volume consumers in the formal area (Muller, 2008a: 73). Following Durban's experience, the ANC during the local government election campaign promised the free basic water to the people (ANC, 2000). It was finally decided to provide 6000 litres of free water to be given to each poor household and detailed guidelines were prepared by the DWAF (DWAF 2002). In fact, free basic water has been seen as part of the social wage in South Africa (SARPN, 2003). The municipalities in South Africa have responded differently to this policy. For example, Tswane provided $6 \mathrm{KL}$ free water to all, but later changed the policy to provide to only poor people. Johannesburg city provides 6KL free water to all but poor people get 10KL free. Durban

38 The water for domestic use is part of Reserve as defined in the section 1 of the National Water Act of 1998 (Schedule 1 use). This includes water for drinking, for food preparation and for personal hygiene and is to be provided free. Other claims on water uses which must be met before the water can be allocated between competing users or in the market are: water use for long-run ecological sustainability, international obligations, and inter-basin transfers. Water available after meeting the above five claims (allocatable under Schedule 1 to Act, basic human needs, long-run ecological sustainability, international obligations, and inter-basin transfers) is called economic use and subject to pricing (National Water Act,1998, Chapter 5, Section 56 (1) of NWA, 1998). 
provides $6 \mathrm{KL}$ free water to all. Port Elizabeth city provides free water only to poor. In brief, there is a trend of providing free water not to all but to poor only.

The human right to water use is legally prescribed by the South African constitution. Some important legal cases in the South African courts have led to far-fetching changes in terms of implementation of water law in the country. The case of Bon Vista Mansions vs. Southern Metropolitan Local Council is a case of significant jurisdictional value with respect to free basic water use. The residents of the Bon Vista Mansions block of flats were disconnected of water supply due to non-payment of water bills by the local council (Tewari, 2009b; see also www.communitylawcentre.org.za/socio-economic rights). The Court ruled in favour of Bon Vista Mansions on grounds of constitutional rights assigned to citizens as per Section $27(1 \mathrm{~b})$ of South African Constitution. The victory finally led to the restoration of water supply to the Phiri residents. The human right to water thus superseded the contractual right between the city and residents.

In the court case of Manqele vs. Durban Transitional Metropolitan Council in 2002, the court ruled that there exist no clear guidelines with respect to minimum standard of water supply services to support life and personal hygiene, as per the South African Water Services Act 108 of 1997. The court further ruled that Manqele's right to water incomplete and not enforceable as he was already consuming 6KL per month (Tewari, 2009b; www. righttowater.org.uk/code_legal2.asp). This further spurted the debate on the limit of free basic water in the country.

The 6KL limit to free basic water was later challenged in July of 2006 by the five residents of Phiri in Soweto in the South Gauteng High Court. The key expert witness, Dr Peter Gleick, testified that the limit be raised from 20 to 50 litres per day per person. The other arguments that the resident used to defend their case was based on the de-facto situation of water use in Soweto. That is the average size of household in Phiri was 16 people, thus the current free basic water provided at the rate of 20 litres per day lasted not more than 12 days in a month. The residents thereafter were forced to buy as the prepaid meters automatically shut off - a difficult reality for unemployed poor people. The South Gauteng High Court in April 2008 declared the prepaid meters unlawful and unfair and a supply of 50 litres per day per person was enjoined on the Johannesburg City. The case went to Supreme Court of Appeal, which also ruled in favor of applicants with different terms and rulings. The Supreme Court suggested that 50 litres be reduced to 42 litres and prepaid meters were found not necessarily unconstitutional. On cross-appeal, the case later went to the Constitutional Court which gave its decision on 8 October, 2009 (Constitutional Court of South Africa, 2009). The Constitutional court upheld that prepaid water meters were neither unfair nor discriminatory and that the quantity of free basic water was to be determined by the government, rather than by the court. A timeline of developments which culminated into the Free Basic Water (FBW) programme in South Africa is produced in Table 2. 
Table 2: Timeline of free basic water policy and programme, South Africa

\begin{tabular}{|c|c|}
\hline Date & Event \\
\hline 1992 & Rio Earth Summit defined water as social and economic good. \\
\hline 1994 & $\begin{array}{l}\text { Under the Reconstruction and Development Plan (RDP), the National Water } \\
\text { and Sanitation programme was conceptualized to provide clean water supply of } \\
\text { 20-30 litres per day to all households within } 200 \text { meters. }\end{array}$ \\
\hline 1996 & $\begin{array}{l}\text { The right to sufficient water was included in the South African Constitution } \\
\text { [Section 27(1)]. }\end{array}$ \\
\hline 2000 & $\begin{array}{l}\text { Durban Municipality was a pioneer in providing FBW to people. Following } \\
\text { Durban's experience, ANC's manifesto for local government election promised } \\
\text { the FBW. }\end{array}$ \\
\hline $\begin{array}{l}\text { September, } \\
2000\end{array}$ & $\begin{array}{l}\text { President Mbeki announced the Free Basic Water policy and the local } \\
\text { government were made responsible for delivery on that promise. }\end{array}$ \\
\hline $\begin{array}{l}\text { Aug } 2000- \\
\text { Feb } 2002\end{array}$ & Some 10 ooo people fell sick and 259 people died of cholera. \\
\hline 29 April 2001 & $\begin{array}{l}\text { David Erleigh, a Councillor suggested that water tariffs would be increased to } \\
\text { cover R33 million - the cost of free basic water. }\end{array}$ \\
\hline $\begin{array}{l}\text { September, } \\
2001\end{array}$ & $\begin{array}{l}\text { Bon Vista Mansions vs Southern Metropolitan Local Council. The Court ruled } \\
\text { in favour of Bon Vista Mansions on the basis of Section } 27 \text { (1a) of South African } \\
\text { constitution. }\end{array}$ \\
\hline 2002 & $\begin{array}{l}\text { Manqele V. Durban Transitional Metropolitan Council court rules that it had } \\
\text { no clear guidelines regarding the prescribed minimum standard of water supply } \\
\text { necessary for households. }\end{array}$ \\
\hline 20 Jan 2003 & $\begin{array}{l}\text { UN Committee on Economic, Social and Cultural rights accepts that everybody } \\
\text { is entitled to human rights to water as emanating from articles } 11 \text { and } 12 \text { of the } \\
\text { International Covenant and Economic and Social Rights (ICESCR) }\end{array}$ \\
\hline $20 \mathrm{Feb} 2003$ & $\begin{array}{l}\text { Dr. Tshabalala Msimang added that free basic water programme was being } \\
\text { implemented by the local governments across the country and covers some } 71 \\
\text { per cent of municipalities in South Africa. }\end{array}$ \\
\hline July 2006 & $\begin{array}{l}\text { Residents of Phiri vs Johannesburg Water. Johannesburg High Court declared } \\
\text { prepaid water unconstitutional. Following it, Cape Town also increased the } \\
\text { amount of FBW to 1okl per household per month. }\end{array}$ \\
\hline
\end{tabular}

The economics of water use is intricately related to demand and supply situation of the water in the country. Of the total water available, some 60 per cent is used in agriculture alone; the manufacturing, mining, and energy sectors put together consume other 15 per cent of the total. The remainder 25 per cent is used up in the domestic sector covering drinking and sanitation needs. Some estimates suggest that demand already 
exceeds supply in 80 per cent of catchments of South Africa; the shortfall is being made up through inter-catchment transfer and scope of further transfer is considered being limited (Ashton et al., 2008).

South African situation is characterized by two sectors or dual economy (Temple, 2005): There is a sector in the economy which is quite rich and can afford to pay for water as this constitutes a very small proportion of the total consumer expenditures. And, there is other sector which has very small disposable income and cannot even afford to pay for basic necessities such as water. The dual policy model entails that these sectors should be treated differently for producing desired developmental outcomes. This has resulted into a policy of market-led allocation of water for the developed sector and the policy of free basic water to underdeveloped sector. The stepwise linear water rates are applied such that high water volume consumers cross-subsidize the indigent citizens, involving a small income transfer as would be evident later in this study.

\section{The Human Rights-Based Water Policy: Free Basic Water Programme}

Water privatization initiative by the IMF and World Bank is defended on the ground of efficiency. However, the evidence in support is not universal. For example, the failed experiment of water privatization in Philippines is a good example to be quoted (Hale, 2007). Also, water privatization programmes have not worked very well in many countries of Africa and costs of these programmes are borne by poor people. Water is not just an economic good and have large social footprint, we should not manage water as an economic commodity alone. If we did, it may have severe repercussions for poor people of the world-poor people are also resource for the economy. They do many jobs what many rich employed would not like to do. The rights-based approach to development is built on the premise that these indigent citizens can contribute the wealth creation in the country if they are ensured of their minimum rights as human beings. The South Africa has thus opted for a mix of right- and market-based approaches to allocation of water, rather than completely resorting to markets only.

The estimates of delivery of clean water and sanitation since 1994/95 till 2009 are given in Table 3 . 
Table 3: Access to clean water and sanitation, South Africa, 1994-2009

\begin{tabular}{|l|l|l|l|}
\hline Year & $\begin{array}{l}\text { Per cent of } \\
\text { households } \\
\text { with access to } \\
\text { clean water }\end{array}$ & $\begin{array}{l}\text { Per cent of households } \\
\text { with access to sanitation }\end{array}$ & Particular details \\
\hline $1994 / 95$ & 60 & 49 & $\begin{array}{l}\text { By December, 2004, some10 } \\
\text { million people had access to clean } \\
\text { water }\end{array}$ \\
\hline 2003 & 85 & 63 & \\
\hline 2009 & 86.1 & $77.1^{*}$ & . \\
\hline
\end{tabular}

*Figures for 2008/9 from The Presidency, RSA (2009) and see Government of South Africa, 6 January, 2010. Source: Constructed from data obtained from UNDP (2005); DWAF website, and The Presidency, RSA (2009).

It will be interesting to note that the proportion of households with access to clean water increased from 6o per cent of all households in 1994/95 to 85 per cent in 2003, and 86 per cent by the end of 2009. Similarly the access to sanitation increased from 49 per cent of household in 1994/95 to 63 per cent in 2003, and 77 per cent by the end of 2009 (Table 3). As per the Millennium Development Goal No 7 of South Africa, the state should halve the proportion of people without sustainable access to safe drinking water by 2015 (UNDP, 2005: 49). Looking at the achievement as stated above, South Africa is way ahead of the goal and commendable progress has been made.

By the end of 2009, some 42.50 million out of 49.74 million people, which is 85.4 per cent of total population, are served with free basic water (Table 4 ).

Table 4: Population served under free basic water programme by 31 December, 2009

\begin{tabular}{|l|l|l|l|l|l|l|}
\hline Province & $\begin{array}{l}\text { Total } \\
\text { Population } \\
\text { Millions }\end{array}$ & $\begin{array}{l}\text { Served } \\
\text { Millions }\end{array}$ & Per cent & $\begin{array}{l}\text { Total poor } \\
\text { population }\end{array}$ & $\begin{array}{l}\text { Served } \\
\text { Millions }\end{array}$ & Pillions \\
\hline Western Cape & 5.28 & 5.04 & 95.4 & 0.80 & 0.78 & 97.8 \\
\hline Eastern Cape & 6.51 & 4.88 & 75.1 & 3.62 & 2.86 & 78.9 \\
\hline Northern Cape & 1.03 & 0.98 & 94.7 & 0.38 & 0.35 & 93.1 \\
\hline Free State & 2.81 & 2.62 & 93.0 & 1.54 & 1.53 & 99.6 \\
\hline KwaZulu-Natal & 10.65 & 8.73 & 82.0 & 5.93 & 4.71 & 79.5 \\
\hline North West & 3.47 & 2.88 & 83.2 & 1.65 & 1.37 & 83.1 \\
\hline Gauteng & 10.88 & 9.61 & 88.3 & 3.84 & 3.44 & 89.8 \\
\hline
\end{tabular}


D. D. Tewari: Spawning Economic Development

\begin{tabular}{|l|l|l|l|l|l|l|}
\hline Mpumalanga & 3.71 & 3.39 & 91.5 & 2.11 & 1.87 & 88.8 \\
\hline Limpopo & 5.40 & 4.36 & 80.8 & 3.27 & 2.85 & 87.3 \\
\hline Total (RSA)* & 49.74 & 42.50 & 85.43 & 23.14 & 19.79 & 85.51 \\
\hline
\end{tabular}

* Totals are rounded up.

1. Total number of people in poor household and a poor household has an income of less than R8oo per month.

2. The population that receives basic water supply at no charge/ for free.

Source: Computed from data obtained from the website of Department of Water Affairs and Forestry at http:// www.dwaf.gov.za.

Of the total 169 water service authorities in the country, all, except four, have the FBW programme and, some 92 per cent of the total population had access to safe water compared to about 66 per cent in 1994 (DWAE, 2009) ${ }^{39}$. These estimates confirm the commendable achievement of the country. For example, it is estimated that without free basic water to all the mean monthly consumption in Tswane city declined from 12.6 to 5.6 Kilolitres which is below the 6 KLs per month as per World Health Organization (WHO) recommendation (Szabo, 2009).

It is estimated that implementing the free basic water policy could cost about R6 to 8/ $\mathrm{KL}$ for treatment of water, the cost of $6 \mathrm{KL} / \mathrm{month}$ to consumers would be about from $\mathrm{R}$ 36 (average cost scenario) to R50 (high cost scenario) per month (Muller, 2008b). This cost rule just indicates the projections, not necessarily generalization for all situations. Furthermore, these costs include infrastructure costs as well (Muller, 2010) ${ }^{40}$. And, using this cost rule, estimate of total costs of providing free basic water to all households and poor households are estimated under two scenarios and are presented in Table 5 .

39 However, some rough estimates suggest that about 75 percent of all free water in the country is delivered to people who have the purchasing power to pay (DWEA, 2009).

40 Dr. Muller was then working with the DWAF and was responsible for the FBW programme. 
Table 5: Some aggregate cost estimates of the free basic water programme, December, 2009, South Africa

\begin{tabular}{|l|l|l|l|l|l|}
\hline & & \multicolumn{2}{l|}{ High Cost Scenario } & \multicolumn{2}{l|}{ Average Cost Scenario } \\
\hline Particulars & $\begin{array}{l}\text { Numbers of } \\
\text { households } \\
\text { (HHs) }\end{array}$ & $\begin{array}{l}\text { Monthly } \\
\text { total costs in } \\
\text { million Rands }\end{array}$ & $\begin{array}{l}\text { Annual total } \\
\text { costs in } \\
\text { billion Rands }\end{array}$ & $\begin{array}{l}\text { Monthly } \\
\text { total costs in } \\
\text { million Rands }\end{array}$ & $\begin{array}{l}\text { Annual } \\
\text { total costs } \\
\text { in billion } \\
\text { Rands }\end{array}$ \\
\hline Total HHs & 13106206 & 655.310 & 7.863 & 471.823 & 5.661 \\
\hline $\begin{array}{l}\text { Served } \\
\text { HHs }\end{array}$ & 11284325 & 564.216 & 6.771 & 406.235 & 4.875 \\
\hline $\begin{array}{l}\text { Total poor } \\
\text { HHs }\end{array}$ & 5839848 & 291.992 & 3.504 & 210.234 & 2.523 \\
\hline $\begin{array}{l}\text { Served } \\
\text { poor HHs }\end{array}$ & 5054454 & 252.722 & 3.032 & 181.900 & 2.184 \\
\hline
\end{tabular}

Source: Estimated

The total cost of free basic water comes to about R565 million per month or R6.77 billion per annum under high cost scenario. Total costs of free water provision to poor household comes to about R253 million per month or about R 3.03 billion per annum-roughly 45 per cent of the total costs of free basic water to the entire nation. Interestingly enough, about 44.7 per cent (5054 454 out of 11284325 households, see Table 5) of total households that receive free water are poor who cannot afford to pay. About 55 per cent of total households have the purchasing power to pay for basic water but have been exempted from paying for this. The cost of serving the poor households is recouped by structuring the tariff appropriately and charging incrementally high tariff for higher water consumption. That means some 55 per cent of the households (richer ones) are paying for the 45 per cent of households (poor ones). If all household are provided with free water (that is about 13106206 household), the aggregate costs of FBW would come to about 655 million per month or 7.86 billion per annum (Table 5 above). These cost estimates are on higher side; the average cost scenario estimates suggest that the costs of free basic water may not be that high as understood in the policy or business circles. In terms of national financial and budget situation, these investments are a very small proportion but contribute a lot in terms of improving human development conditions. This is of colossal importance with respect to South Africa attaining its millennium development goals with respect to water and food.

The development of free basic water has not transpired in vacuum. Rather it has brought a number of indirect benefits to the country as well. For example, it has acted as enabling people in rural areas to do tasks and develop capacities of managing their own affairs. These institutional innovations have come up in the form of improved local government, 
private sector or community based operations. The new government has made the delivery of services to people as the major goal and all possible efforts are being made to succeed. In terms of the Human Development Index (HDI), there has been a steady progress after 2000. For example, HDI declined from 0.698 in 1990 to 0.688 in 2000 and 0.678 in 2005; only after 2005 it has registered an upward trend. It touched 0.680 in 2006 and 0.683 in 2007 (United Nations, 2009)

\section{Conclusions and Policy Implications}

South Africa is a dual economy, possessing both developed and underdeveloped sectors. South Africa is also a water stressed country and water supplies are limited. It needs to use water efficiently for its development. A compromise to use water judiciously and equitably is made by the South African government; that is the market-led water allocation for the developed sector and the rights-based allocation for the under-developed sector.

The human right to water is guaranteed in the South African constitution and court decisions have insisted that government live up to its promise. About 84.4 per cent of the population is getting free basic water supply as per the latest estimate provided by the Department of Water Affairs ${ }^{41}$. The free basic water programme was brainchild of the ANC and the present Zuma government has shown further commitment to fulfil that promise. Delivery of services of water among other basic things has been the key point of contestation of recent municipal election of 2011 and ANC has won election again. In the language of development economics, the current rights-based approach to uplift the indigent citizen population has made sense and it is working despite criticism from some quarters.

41 Forestry is now moved to the Ministry of Agriculture and Department of Water and Environmental Affairs (DWEA) is under the Ministry of Water and Environmental Affairs. 


\section{References}

Ashton P. J., Hardwick D., and Breen C.M. (2008). Changes in water availability and demand within South Africa's shared river basins as determinants of regional socialecological resilience. In: M.J. Burns and A.V.B. Weaver (Eds.). Exploring Sustainability Science: A Southern African Perspective: (279-310). Stellenbosch: Stellenbosch University Press.

African National Congress (ANC) (1994). "Reconstruction and Development Programme, "African National Congress, Johannesburg.

African National Congress (ANC) (2000). "Local Government Elections 2000 Manifesto," African National Congress, Johannesburg.

Asmal, K. (1996). Budget Speech, National Assembly (28 May) Cape Town.

Balfour A.F, Wilson I. De Jager J., Still D. A. and Louw S. (2005). "Development of Models to Facilitate the Provision of Free Basic Water in Rural Areas." WRC Report No 1379/1/05. Pretoria: Water Research Commission (WRC).

Bayliss, K. (2001). Water Privatization in Africa: Lessons from Three Case Studies. Public Services International Research Unit (PSIRU), Park Row, London: University of Greenwich.

Bentham Jeremy., (1781, 2000). An Introduction to the Principles of Morals and Legislation, Kitcher: Batoche Books.

Blumel E.B. (2004). The implications of formulating a human right to water. Ecology Law Quarterly, 31, pp. 957-1006.

Brocklehurst, C. (2001). Durban Metro Water: Private Sector Partnership to Serve the Poor. Water and Sanitation Programme- Africa, Case Study, Nairobi: WSP.

Camdessus et al. (2003) "Financing Water for All." Report of the World Panel on Financing Water Infrastructure, World Water Council and Global Partnership.

Cornwall. A and Nyamu-Musembi .C (2004). "Putting the "rights-based approach" to development into perspective." Third World Quarterly 25(8), pp. 1415-1437.

Constitutional Court of South Africa (2009) Lindiwe Mazibuko and Others vs City of Johannesburg and Others, Case CCT 30/o9 (2009), ZACC 28. Date of Judgment 8 October, 2009 .

Department of Water Affairs and Forestry (DWAF) (1994). Water Supply and Sanitation Policy, White Paper, Pretoria: DWAF.

Department of Water Affairs and Forestry (DWAF) (1997). A National Water Policy for South Africa, White Paper, Pretoria: DWAF. 
Department of Water Affairs And Forestry (DWAF) (2002). Free Basic Water Implementation Guidelines for Local Authorities, Version 2.3, Pretoria: DWAF.

Department Of Water Affairs and Forestry (DWAF) (2009). The price of free water in South Africa, Global Water Intelligence: Market Leading Analysis of the International Water Industry, 10 (8): 2-3 [online].

Available: http://www.globalwaterintel.com/archive/10/8/general/price-free-watersouth-africa.html

Dubreiul Celine (2006). "The right to water: from concept to implementation." World Water Council. Available at: http://www.worldwatercouncil.org/fileadmin/wwc/Library/ Publications_and_reports/RightToWater_FinalText_Cover.pdf

Durnev, A., V. Errunza, and A. Molchanov (2009). "Property rights protection, corporate transparency, and growth." Journal of International Business Studies 40, pp. 1533-1562.

Gleick, P.H, (2000). "The changing water paradigm: A look at twenty-first century water resources development.” Water International 25, pp.127-138.

Gleick, P.H, Wolf Gary, Elizabeth, and L. Chalecki R.R (2002). The New Economy of Water: The Risks and Benefits of Globalization and Privatization of Fresh Water. Pacific Institute for Studies in Development, California: Environment and Security.

Gleick, P.H, (1999). “The human right to water.” Water Policy. 1(5), pp. 487-503.

Government of South Africa (GSA) (2010). South African Minister discusses water supply situation in South Africa, 6 January, 2010. Available at: http://www.egovmonitor.com/ node/32401/print.

Grusky Sara, (2001). "Privatization tidal wave IMF/World Bank water policies and the price paid by the poor." The Multinational Monitor. 22(9), pp.1-8.

Hale. S (2007). "The significance of justiciability: legal rights, development, and the human right to water in Philippines." SAIS Review. 27(2). pp. 139-150.

Hart Hla (1955). “Are there any natural rights?” The Philosophical Review 64(2), pp. 175191.

Hart Hla (1973). "Bentham on legal rights." In: Simpson, AWB (ed). Oxford Essays in Jurisprudence, Second Series, Oxford: Clarendon Press, 171; Reprinted in his Essays in Jurisprudence and Philosophy, Oxford: Clarendon Press, 1982, 162.

Hart Hla (1979). “Between utility and rights.” In: Ryan, A ( ed.). The Idea of Freedom: Essays in 
Honour of Isaiah Berlin. Oxford: Clarendon Press, 77; Reprinted in his Essays in Jurisprudence and Philosophy, Oxford: Clarendon Press, 1983, 198.

Hart Hla (1994). The Concept of Law. $2^{\text {nd }}$ Edition, with posthumous postscript, Bulloch, P \& Raz, J. (Eds), Oxford: Clarendon Press.

Hobbes Thomas (1651). Leviathan. Edwin Curley (Ed.) 1994. Indianapolis: Hackett Publishing.

Human Rights Council of Australia (HRCA) (2001). The Rights Way to Development: A Human rights Approach to Development Assistance. HRCA Inc.

Internet Encyclopaedia of Philosophy, Ethics. Available at: http://www.iep.utm.edu/ ethics. Accessed on 5 January, 2009.

International Conference on Water and Environment (ICWE) (1992). "The Dublin Statement on Water and Sustainable Development," Dublin, Ireland, 26-31 January, 1992.

Mill John Stuart (1969), (1861). “Utilitarianism”, In: Robson, J. ( ed). The Collected Works of John Stuart Mill, Vol. 10, Toronto: Toronto University Press; London: Routledge \& Kegan Paul, 203.

Muller M. (1993). "Water supply and sanitation institutions-using the transition to get it right". Paper presented at the Water Institute of Southern Africa Biennial Conference, Johannesburg, February.

Muller M, (2008a). "Free Basic Water-A Sustainable Instrument for a Sustainable Future in South Africa." Environment \& Urbanization 20 (1): 67-87.

Muller M, (2008b). Personal communication from Muller by email. Visiting Adjunct Professor at the Graduate School of Public and Development Management, University of Witwatersrand. 28 September, 2008.

Muller M, (2010). Personal communication from Muller by email. Visiting Adjunct Professor at the Graduate School of Public and Development Management, University of Witwatersrand. 28 January, 2010.

Organization of African Union (OAU) (1981). The African (Banjul) Charter on Human and People's Rights, Available at: http://www1.umn.edu/humnanrts/instree/z lafchar.htm) (accessed on 6 January, 2010).

Overseas Development Institute (2004). "Right to Water: Legal Forms, Political Channels." ODI Briefing Paper, July 2004. London: Overseas Development Institute.

Republic of South Africa (RSA) (1996a). The Constitution of the Republic of South Africa, Cape Town: Juta. 
Republic of South Africa (RSA) (1996b). Growth Employment and Redistribution (GEAR): A Macroeconomic Strategy, Pretoria, Republic of South Africa.

Republic of South Africa (RSA) (1997). The Water Services Act NO. 108 of 1997. Cape Town: Government Gazette Volume 30 No. 18522. 19 December 1997.

Standing Committee on Water Supply and Sanitation (SCOWSAS ) (1991). "Status Report." Johannesburg, Mimeo. Cited in Muller (2008a).

SARPN (2003). Inequality and the Social Wage in South Africa: Debating Aspects of the Ten Year Review. Southern African Regional Poverty Network, Pretoria. Available at: http:// www.saprn.org.za/documents/doooo589/socal_wage_South Africa.pdf. (accessed on 23 January, 2009).

Stephen F. Austin State University, No date, see for more details, http://www2.sfasu.edu/ polisci/abel/ConstitutionalLawII/RightsTheory.htm

Szabo Andrea (2009). “The Value of Free Water: Analyzing South Africa's Free Basic Water

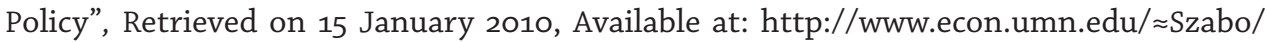
jmpszabo_nov22.pdf.

Temple J. (2005). "Dual economy models: a primer for growth economists." The Manchester School. 73(4), pp. 435-478.

Tewari D.D. (2009a). “A detailed analysis of evolution of water rights in South Africa: An account of three and half centuries, from 1652 AD to present." Water SA 35(5), pp.693-710.

Tewari D.D. (2009b). "Free basic water and economic development: can they co-exist?" Water Wheel Jan/Feb, pp. 33-35."

The Presidency (RSA) (2009). Development Indicators, Government of South Africa, Pretoria.

Thompson B. (2003). "Water wars rage in Detroit and South Africa." The Michigan Citizen. 4th February.

United Nations (1948). Universal Declaration of Human Rights, Adopted and proclaimed by the General Assembly resolution 217A (III) of 10 December, 1948. Available at: http:// www.un.org/endocuments/udhr/ (accessed on 5 January, 2010).

United Nations (1966). "International Covenant on Economic, Social and Cultural Rights," Adopted on 16 December, 1966. Available at: http://en.wikipedia.org/wiki/international_ covenant_on economic and cultural rights. (Accessed on 7 January, 2010).

United Nations Conference on Trade and Development (UNCTAD) (1992). "Report of the United Nations Conference on Environment and Development," Rio de Janeiro (A/Conf. 151/26), UN, New York, Chapter 8.

110 GJDS, Vol. 8, No. 1, May 2011 
United Nations (1979). The Convention on the Elimination of All Forms of Discrimination against Women (CEDAW)." Available at: http://www.un.org/womenwatch/daw/cedaw/ text/econvention.htm) (accessed on 6 January, 2010).

United Nations, Committee on Economic, Social And Cultural Rights (UNCESCR) (2002), General Comment No. 15: Substantive Issues Arising in the Implementation of the International Covenant on Economic, Social and Cultural Rights. (11-29 November 2002).

United Nations Development Programme (UNDP) (2005). South Africa: Millennium Development Goals, Country Report, UNDP. 75pp. The summary is available at the UNDP website. MDGs in South Africa, available at: http://www.undp..org.za/index.php/mdgs-insouth Africa, Accessed on 21 January, 2010.

United Nations Development Programme (UNDP) (2006). Applying A Human Rights-Based Approach to Development Cooperation and Programming: A UNDP Capacity Development Resource. Capacity Development Group, Bureau for Development Policy, UNDP.

United Nations (2009). Human Development Report, New York: United Nations. Available at: www.undp.org/hdr/2009.shtml.

United Nations (2010). GA Resolution 64/292, UN Document A/RES/64/292, 3 August. 2010. Available at: GA Res 64/292, UN Doc A/RES/64/292, 3 August 2010, available at :http:// daccessddsny.un.org/doc/UNDOC/GEN/Nog/479/35/PDF/No947935.pdf?OpenElement. Accessed on 19 may, 2011.

UNFPA and Harvard School of Public Health (2010). A Human Rights-Based Approach to Programming: Practical Implementation Manual and Training Materials. New York: UNFPA.

World Health Organization (WHO) (200o). The Global Water Supply and Sanitation Assessment 2000, at 1.1 (2000), available at: http://www.who.int/docstore/water saniatation_health/Globalassessment/GlobalTOC.hm.

Accessed on 5 January, 2011. 